\title{
BIOCHEMICAL STUDIES IN IDIOPATHIC HYPERCALCAEMIA OF INFANCY
}

\author{
BY \\ JOHN O. FORFAR, S. L. TOMPSETT and W. FORSHALL \\ From the Departments of Paediatrics and Biochemistry, Edinburgh Northern Group of Hospitals, and the Departments \\ of Child Life and Health and Clinical Chemistry, University of Edinburgh
}

(RECEIVED FOR PUBLICATION MAY 21, 1959)

Part I. Serum Calcium and Cholesterol Levels from the First to the Fifteenth Month of Life

Idiopathic hypercalcaemia tends to develop between the first and fifteenth months of life and diagnosis rests primarily on biochemical findings. We have determined for this age period the normal values for serum calcium, serum cholesterol and the serum cholesterol fractions by the methods which we use.

Over a period of four years samples of blood were taken from 110 infants in hospital, or attending hospital, who required venupuncture. None was suffering from idiopathic hypercalcaemia, diabetes, nephrosis or hypothyroidism.

\section{Methods}

Serum Calcium. Initially the method of Kramer and Tisdall (1921) and Tisdall (1923) was employed in which calcium is precipitated as calcium oxalate and titrated with potassium permanganate. Two $\mathrm{ml}$. of serum are required. Later Trinder's (1957) method was used in which calcium is precipitated with chloranilic acid; the precipitate is dissolved in a colour reagent consisting of ferric nitrate and sulphuric acid and the result determined colorimetrically by comparison with a similarly treated standard calcium solution. This method requires only $0.5 \mathrm{ml}$. of serum.

Serum Cholesterol. Total serum cholesterol was determined by the method of Zlatkis, Zak and Boyle (1953), in which a direct colour reaction is obtained by the addition of a ferric chloride/glacial acetic acid/ concentrated sulphuric acid mixture. No preliminary extraction is necessary and only $0.1 \mathrm{ml}$. of serum is required.

Free cholesterol was estimated by the method of Zak, Dickenman, White, Burnett and Chemey (1955) in which free cholesterol is precipitated from an alcohol-acetone extract with digitonin, the resulting digitonide separated and its cholesterol content estimated by the method of Zlatkis et al. (1953). One ml. of serum is required.
Cholesterol esters which are not precipitated by digitonin were estimated by difference.

\section{Results}

A comparison between the Kramer and Tisdall and Trinder methods of calcium estimation is given in Table 1. Both methods were applied to random

TABLE 1

COMPARISON BETWEEN KRAMER AND TISDALL AND TRINDER METHODS OF ESTIMATING SERUM CALCIUM. CARRIED OUT ON 30 RANDOM SAMPLES OF ADULT BLOOD

\begin{tabular}{|c|c|}
\hline \multicolumn{2}{|c|}{ Serum Calcium (mg. \%) } \\
\hline $\begin{array}{l}\text { Kramer } \\
\text { and } \\
\text { Tisdall }\end{array}$ & Trinder \\
\hline $\begin{array}{r}13 \cdot 9 \\
7 \cdot 7 \\
9 \cdot 1 \\
8 \cdot 3 \\
8 \cdot 8 \\
8 \cdot 7 \\
9 \cdot 0 \\
7 \cdot 1 \\
13 \cdot 3 \\
9 \cdot 4 \\
14 \cdot 5 \\
9 \cdot 4 \\
8 \cdot 8 \\
9 \cdot 4 \\
9 \cdot 9 \\
8 \cdot 9 \\
9 \cdot 0 \\
8 \cdot 8 \\
10 \cdot 2 \\
9 \cdot 0 \\
10 \cdot 5 \\
8 \cdot 6 \\
8 \cdot 8 \\
8 \cdot 2 \\
8 \cdot 7 \\
10 \cdot 1 \\
10 \cdot 1 \\
14 \cdot 5 \\
9 \cdot 1 \\
9 \cdot 2\end{array}$ & $\begin{array}{r}13 \cdot 2 \\
7 \cdot 6 \\
9 \cdot 2 \\
7 \cdot 6 \\
9 \cdot 1 \\
8 \cdot 8 \\
9 \cdot 0 \\
6 \cdot 6 \\
13 \cdot 4 \\
9 \cdot 2 \\
14 \cdot 5 \\
9 \cdot 8 \\
9 \cdot 2 \\
9 \cdot 5 \\
9 \cdot 4 \\
9 \cdot 0 \\
8 \cdot 8 \\
8 \cdot 8 \\
9 \cdot 9 \\
8 \cdot 5 \\
10 \cdot 3 \\
9 \cdot 0 \\
8 \cdot 7 \\
8 \cdot 5 \\
8 \cdot 5 \\
10 \cdot 1 \\
9 \cdot 9 \\
13 \cdot 7 \\
9 \cdot 0 \\
9 \cdot 2\end{array}$ \\
\hline ige 9.7 & $9 \cdot 6$ \\
\hline
\end{tabular}


TABLE 2

SERUM CALCIUM, TOTAL CHOLESTEROL, FREE CHOLESTEROL AND CHOLESTEROL ESTER ESTIMATIONS IN 110 INFANTS

믄

\begin{tabular}{|c|c|c|c|c|c|c|c|c|c|c|c|}
\hline No. & $\begin{array}{c}\text { Age } \\
\text { (mth.) }\end{array}$ & $\begin{array}{l}\text { Weight } \\
\text { (lb. oz.) }\end{array}$ & Sex & $\begin{array}{l}\text { Serum } \\
\text { Calcium } \\
(\mathrm{mg} \% \%)\end{array}$ & $\begin{array}{l}\text { Total } \\
\text { Chol. } \\
\text { (mg.\%) }\end{array}$ & $\begin{array}{c}\text { Free } \\
\text { Chol. } \\
\text { (mg. \%) }\end{array}$ & $\begin{array}{l}\text { Chol. } \\
\text { Ester } \\
\text { (mg.\%) }\end{array}$ & $\begin{array}{l}\text { Free } \\
\text { Chol. } \\
\text { Chol. } \\
\text { Ester }\end{array}$ & $\begin{array}{l}\mathrm{Ca} \times \\
\text { Total } \\
\text { Chol. }\end{array}$ & $\begin{array}{l}\mathrm{Ca} \times \\
\text { Free } \\
\text { Chol. }\end{array}$ & $\begin{array}{l}\mathrm{Ca} \times \\
\text { Chol. } \\
\text { Ester }\end{array}$ \\
\hline $\begin{array}{r}1 \\
2 \\
3 \\
3 \\
4 \\
5 \\
67 \\
7 \\
99 \\
10 \\
11 \\
12 \\
12 \\
14 \\
14 \\
15 \\
16 \\
17 \\
18\end{array}$ & 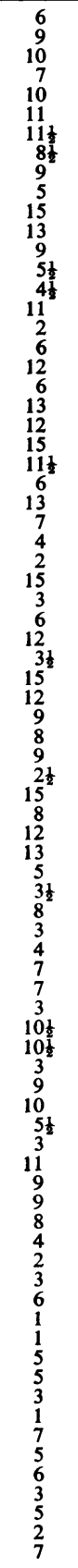 & 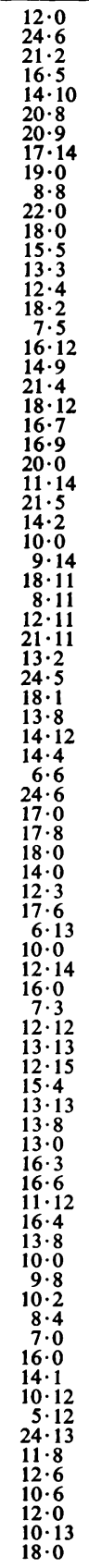 & $\begin{array}{l}\mathbf{M} \\
\mathbf{M} \\
\mathbf{M} \\
\mathbf{M} \\
\mathbf{M} \\
\mathbf{M} \\
\mathbf{F}\end{array}$ & 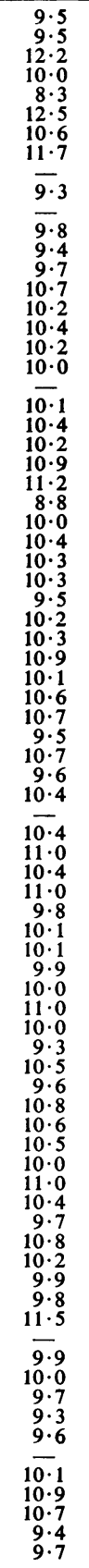 & $\begin{array}{l}162 \\
106 \\
165 \\
133 \\
135 \\
196 \\
208 \\
233 \\
237 \\
144 \\
183 \\
212 \\
204 \\
139 \\
175 \\
204 \\
166 \\
179 \\
129 \\
200 \\
162 \\
157 \\
208 \\
237 \\
174 \\
226 \\
148 \\
159 \\
222 \\
231 \\
150 \\
150 \\
211 \\
177 \\
218 \\
258 \\
1162 \\
171 \\
164 \\
289 \\
2233 \\
200 \\
1444 \\
154 \\
2100 \\
175 \\
202 \\
202 \\
280 \\
154 \\
241 \\
237 \\
183 \\
2233 \\
229 \\
229 \\
1771 \\
192 \\
2177 \\
2100 \\
133 \\
183 \\
142 \\
188 \\
275 \\
178 \\
250 \\
188 \\
204 \\
2099 \\
149 \\
2177 \\
192 \\
217 \\
158\end{array}$ & 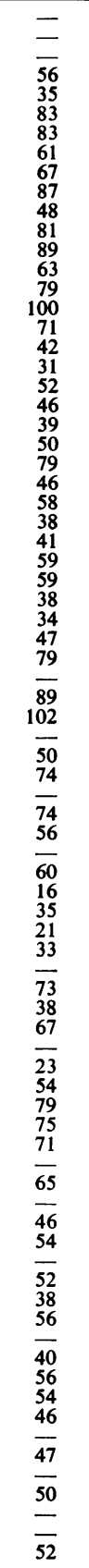 & 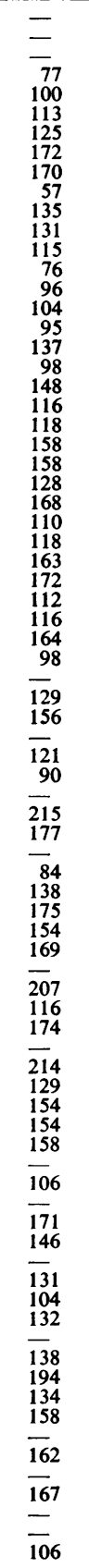 & $\begin{array}{c} \\
\bar{Z} \\
.727 \\
.350 \\
.735 \\
.664 \\
.355 \\
.394 \\
1.526 \\
.356 \\
.618 \\
.775 \\
.824 \\
.962 \\
.748 \\
.307 \\
.316 \\
.352 \\
.331 \\
.316 \\
.500 \\
.359 \\
.345 \\
.345 \\
.362 \\
.343 \\
.339 \\
.293 \\
.287 \\
.806 \\
.690 \\
.654 \\
.413 \\
.828 \\
.344 \\
.316 \\
.715 \\
.116 \\
.200 \\
.138 \\
.196 \\
.353 \\
.328 \\
.385 \\
.108 \\
.418 \\
.513 \\
.487 \\
.444 \\
.613 \\
.6799 \\
.370 \\
.3977 \\
.366 \\
.424 \\
.290 \\
.289 \\
.403 \\
.291 \\
.291 \\
.300 \\
.491\end{array}$ & 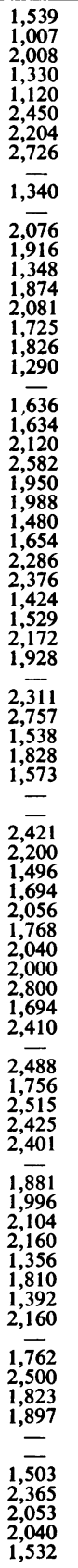 & 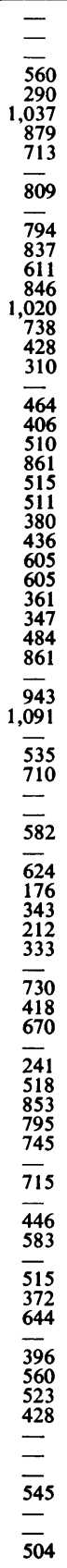 & 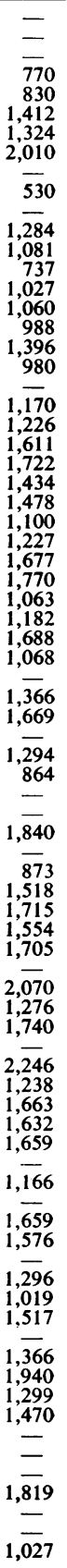 \\
\hline
\end{tabular}


TABLE 2-contd.

\begin{tabular}{|c|c|c|c|c|c|c|c|c|c|c|c|}
\hline No. & $\begin{array}{c}\text { Age } \\
\text { (mth.) }\end{array}$ & $\begin{array}{c}\text { Wt. } \\
\text { (lb. oz.) }\end{array}$ & Sex & $\begin{array}{l}\text { Serum } \\
\text { Calcium } \\
\text { (mg. \%) }\end{array}$ & $\begin{array}{c}\text { Total } \\
\text { Chol. } \\
\text { (mg. \%) }\end{array}$ & $\begin{array}{c}\text { Free } \\
\text { Chol. } \\
\text { (mg. \%) }\end{array}$ & $\begin{array}{l}\text { Chol. } \\
\text { Ester } \\
\text { (mg.\%) }\end{array}$ & $\begin{array}{l}\text { Free } \\
\text { Chol. } \\
\text { Chol. } \\
\text { Ester }\end{array}$ & $\begin{array}{c}\text { Ca } \times \\
\text { Total } \\
\text { Chol. }\end{array}$ & $\begin{array}{c}\text { Ca } \times \\
\text { Free } \\
\text { Chol. }\end{array}$ & $\begin{array}{l}\text { Ca } \times \\
\text { Chol. } \\
\text { Ester }\end{array}$ \\
\hline $\begin{array}{l}81 \\
82 \\
83 \\
84 \\
85 \\
86 \\
87 \\
88 \\
89 \\
90 \\
91 \\
92 \\
93 \\
94 \\
95 \\
96 \\
97 \\
98 \\
99 \\
100 \\
101 \\
102 \\
103 \\
104 \\
105 \\
106 \\
107 \\
108 \\
109 \\
110\end{array}$ & $\begin{array}{c}7 \\
2 \frac{1}{2} \\
8 \\
10 \\
7 \\
13 \\
8 \\
2 \\
5 \frac{1}{2} \\
8 \\
1 \\
6 \\
15 \\
1 \\
1 \frac{1}{2} \\
13 \\
14 \\
9 \frac{1}{2} \\
6 \\
13 \\
10 \frac{1}{2} \\
4 \\
15 \\
5 \\
4 \\
4 \\
4 \\
2 \\
5 \frac{1}{2} \\
4\end{array}$ & $\begin{array}{c}14 \cdot 11 \\
9 \cdot 5 \\
10 \cdot 6 \\
14 \cdot 4 \\
18 \cdot 4 \\
21 \cdot 0 \\
13 \cdot 5 \\
6 \cdot 8 \\
11 \cdot 8 \\
11 \cdot 8 \\
7 \cdot 7 \\
13 \cdot 2 \\
23 \cdot 0 \\
8 \cdot 15 \\
5 \cdot 12 \\
16 \cdot 12 \\
23 \cdot 7 \\
22 \cdot 0 \\
11 \cdot 10 \\
17 \cdot 0 \\
18 \cdot 3 \\
10 \cdot 3 \\
13 \cdot 7 \\
11 \cdot 11 \\
11 \cdot 0 \\
8 \cdot 0 \\
7 \cdot 14 \\
12 \cdot 8 \\
18 \cdot 0 \\
10 \cdot 8\end{array}$ & $\begin{array}{l}\mathbf{M} \\
\mathbf{M} \\
\mathbf{M} \\
\mathbf{F} \\
\mathbf{M} \\
\mathbf{M} \\
\mathbf{M} \\
\mathbf{M} \\
\mathbf{F} \\
\mathbf{F} \\
\mathbf{M} \\
\mathbf{M} \\
\mathbf{M} \\
\mathbf{M} \\
\mathbf{M} \\
\mathbf{M} \\
\mathbf{M} \\
\mathbf{M} \\
\mathbf{F} \\
\mathbf{F} \\
\mathbf{F} \\
\mathbf{F} \\
\mathbf{F} \\
\mathbf{F} \\
\mathbf{F} \\
\mathbf{M} \\
\mathbf{F} \\
\mathbf{M} \\
\mathbf{M} \\
\mathbf{M}\end{array}$ & $\begin{array}{r}10 \cdot 2 \\
9 \cdot 7 \\
8 \cdot 9 \\
9 \cdot 7 \\
10 \cdot 0 \\
9 \cdot 6 \\
9 \cdot 5 \\
8 \cdot 9 \\
10 \cdot 1 \\
10 \cdot 3 \\
9.9 \\
9 \cdot 8 \\
8 \cdot 5 \\
8 \cdot 9 \\
9 \cdot 8 \\
10 \cdot 6 \\
10 \cdot 2 \\
11 \cdot 7 \\
9.9 \\
9 \cdot 3 \\
9 \cdot 3 \\
9.9 \\
9.9 \\
10 \cdot 7 \\
9.0 \\
9.8 \\
11 \cdot 1 \\
9 \cdot 1 \\
9 \cdot 8 \\
10 \cdot 3\end{array}$ & $\begin{array}{l}171 \\
171 \\
160 \\
237 \\
194 \\
258 \\
131 \\
177 \\
155 \\
219 \\
196 \\
196 \\
217 \\
190 \\
196 \\
233 \\
279 \\
167 \\
179 \\
175 \\
171 \\
218 \\
282 \\
192 \\
250 \\
202 \\
217 \\
250 \\
225 \\
-\end{array}$ & $\begin{array}{r}71 \\
42 \\
33 \\
42 \\
104 \\
34 \\
52 \\
83 \\
76 \\
84 \\
40 \\
52 \\
65 \\
58 \\
73 \\
\\
56 \\
46 \\
46 \\
54 \\
63 \\
54 \\
68 \\
50 \\
\end{array}$ & $\begin{array}{l}100 \\
129 \\
127 \\
\overline{152} \\
154 \\
97 \\
125 \\
72 \\
143 \\
112 \\
156 \\
165 \\
125 \\
138 \\
160 \\
\overline{1} \\
\overline{123} \\
129 \\
\overline{172} \\
228 \\
129 \\
\overline{148} \\
149 \\
\overline{175} \\
-\end{array}$ & $\begin{array}{l}.710 \\
.326 \\
.260 \\
.727 \\
.676 \\
.351 \\
.416 \\
1 \cdot 154 \\
.532 \\
.751 \\
.256 \\
.316 \\
.520 \\
.420 \\
.457 \\
- \\
.455 \\
.357 \\
. \overline{267} \\
.237 \\
.489 \\
. \overline{365} \\
.456 \\
. \overline{286} \\
-\end{array}$ & $\begin{array}{r}1,743 \\
1,659 \\
1,424 \\
2,298 \\
1,940 \\
2,475 \\
1,244 \\
1,574 \\
1,564 \\
2,255 \\
1,940 \\
1,920 \\
1,844 \\
1,690 \\
1,921 \\
2,368 \\
2,845 \\
1,954 \\
1,771 \\
1,627 \\
1,590 \\
2,159 \\
2,794 \\
2,052 \\
2,250 \\
1,978 \\
2,408 \\
2,274 \\
2,204 \\
-\end{array}$ & $\begin{array}{l}724 \\
407 \\
294 \\
\overline{420} \\
999 \\
323 \\
463 \\
838 \\
783 \\
832 \\
392 \\
442 \\
578 \\
568 \\
773 \\
- \\
\overline{554} \\
427 \\
\overline{455} \\
535 \\
674 \\
\overline{529} \\
755 \\
\overline{490} \\
-\end{array}$ & $\begin{array}{r}1,020 \\
1,250 \\
1,130 \\
\overline{1,520} \\
1,478 \\
922 \\
1,112 \\
727 \\
1,472 \\
1,108 \\
1,528 \\
1,401 \\
1,112 \\
1,352 \\
1,698 \\
-\overline{1,} \\
1, \overline{217} \\
1,199 \\
1, \overline{703} \\
2,256 \\
1,379 \\
1, \overline{449} \\
1,653 \\
1, \overline{715} \\
-\end{array}$ \\
\hline
\end{tabular}

TABLE 3

SERUM CALCIUM, CHOLESTEROL, FREE CHOLESTEROL, CHOLESTEROL ESTERS, FREE CHOLESTEROL/CHOLESTEROL ESTERS RATIO, CALCIUM $\times$ CHOLESTEROL, CALCIUM $\times$ FREE CHOLESTEROL, CALCIUM $\times$ CHOLESTEROL ESTERSMEANS, STANDARD DEVIATIONS AND RANGES

\begin{tabular}{|c|c|c|c|c|c|c|c|c|c|c|}
\hline \multicolumn{6}{|c|}{ Estimation } & \multirow{2}{*}{$\begin{array}{c}\begin{array}{c}\text { Observations } \\
\text { (no.) }\end{array} \\
104 \\
61 \\
43\end{array}$} & \multirow{2}{*}{$\begin{array}{c}\text { Mean } \\
10.11 \mathrm{mg} . \% \\
10.26 \mathrm{mg} \% \\
9.88 \mathrm{mg} \%\end{array}$} & \multirow{2}{*}{$\begin{array}{c}\text { S.D. } \\
0.707 \\
0.693 \\
0.699\end{array}$} & \multirow{2}{*}{$\begin{array}{c}\begin{array}{c}\text { Range } \\
\text { Mean } \pm \text { S.D. } \times 2 \\
(P=0 \cdot 05)\end{array} \\
8 \cdot 7-11 \cdot 5 \mathrm{mg} . \% \\
8 \cdot 9-11 \cdot 6 \mathrm{mg} \% \% \\
8 \cdot 5-11 \cdot 3 \mathrm{mg} \%\end{array}$} & \multirow{2}{*}{$\begin{array}{c}\begin{array}{c}\text { Range } \\
\text { Mean } \pm \text { S.D. } \times 2 \cdot 57 \\
(\mathrm{P}=0 \cdot 01)\end{array} \\
8 \cdot 3-11.9 \mathrm{mg} . \% \\
8 \cdot 5-12.0 \mathrm{mg} \% \% \\
8 \cdot 2-11.6 \mathrm{mg} \%\end{array}$} \\
\hline $\begin{array}{l}\text { Calcium (all results) } \\
\text { Calcium (Kramer ar } \\
\text { Calcium (Trinder m }\end{array}$ & $\begin{array}{l}\text { nd Tisdail } \mathrm{n} \\
\text { lethod) }\end{array}$ & hod) & $\begin{array}{l}\cdots \\
\cdots \\
\cdots\end{array}$ & $\begin{array}{l}\cdots \\
\cdots \\
\cdots\end{array}$ & $\begin{array}{l}\cdots \\
\cdots \\
\cdots\end{array}$ & & & & & \\
\hline $\begin{array}{l}\text { Total cholesterol } \\
\text { Free cholesterol } \\
\text { Cholesterol esters } \\
\text { Free cholesterol/cho }\end{array}$ & 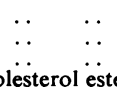 & $\begin{array}{l}\cdots \\
\dot{*} \\
\text { ratio }\end{array}$ & $\begin{array}{l}\cdots \\
\cdots \\
\cdots\end{array}$ & $\begin{array}{l}\cdots \\
\cdots \\
\cdots\end{array}$ & $\begin{array}{l}\cdots \\
\cdots \\
\cdots\end{array}$ & $\begin{array}{r}104 \\
86 \\
86 \\
86\end{array}$ & $\begin{array}{l}194 \mathrm{mg} . \% \\
57 \mathrm{mg} \% \\
137 \mathrm{mg} \% \\
0.453\end{array}$ & $\begin{array}{l}38 \cdot 2 \\
18 \cdot 6 \\
33 \cdot 3 \\
0 \cdot 229\end{array}$ & $\begin{array}{c}118-270 \mathrm{mg} . \% \\
20-94 \mathrm{mg} \% \% \\
70-204 \mathrm{mg} \% \% \\
0-0.9\end{array}$ & $\begin{array}{rl}96-292 & \mathrm{mg} . \% \\
9-105 & \mathrm{mg} . \% \\
51-223 & \mathrm{mg} . \% \\
0-1 \cdot 0 & \end{array}$ \\
\hline $\begin{array}{l}\text { Calcium } \times \text { total chol } \\
\text { Calcium } \times \text { free chole } \\
\text { Calcium } \times \text { cholester }\end{array}$ & $\begin{array}{l}\text { lesterol } \\
\text { esterol } \\
\text { ol esters }\end{array}$ & $\begin{array}{l}\cdots \\
\cdots \\
\cdots\end{array}$ & $\begin{array}{l}\cdots \\
\cdots \\
\cdots\end{array}$ & $\begin{array}{l}\cdots \\
\cdots \\
\cdots\end{array}$ & $\begin{array}{l}\ldots \\
\cdots \\
\cdots\end{array}$ & $\begin{array}{l}98 \\
81 \\
81\end{array}$ & $\begin{array}{r}1,947 \\
583 \\
1,374\end{array}$ & $\begin{array}{l}403 \\
205 \\
348\end{array}$ & $\begin{array}{c}1,141-2,753 \\
173-993 \\
678-2,070\end{array}$ & $\begin{array}{r}914-2,980 \\
56-1,110 \\
481-2,267\end{array}$ \\
\hline
\end{tabular}

samples of blood from adult patients. No significant difference was observed in the results obtained by the two methods.

Table 2 gives the results of the estimation of serum calcium, cholesterol, free cholesterol and cholesterol esters in 110 infants aged 1 to 15 months. In each infant these estimations were carried out on the same specimen of blood. In the first 65 infants calcium was estimated by the Kramer and Tisdall method, thereafter by the Trinder method. The Table also gives the age, weight and sex of the infants and the arithmetical products of calcium and total cholesterol, calcium and free cholesterol and calcium and cholesterol esters. These products are included in view of the suggestion that they might be of value in the diagnosis of idiopathic hypercalcaemia of infancy (Forfar, Balf, Maxwell and Tompsett, 1956).

There is no significant sex difference between serum calcium, total cholesterol, free cholesterol and cholesterol esters levels.

Table 3 gives means, standard deviations and ranges for calcium, total cholesterol, free cholesterol, cholesterol esters, free cholesterol/cholesterol esters ratio, calcium $\times$ cholesterol, calcium $\times$ free cholesterol and calcium $\times$ cholesterol esters. 
TABLE 4

CORRELATIONS

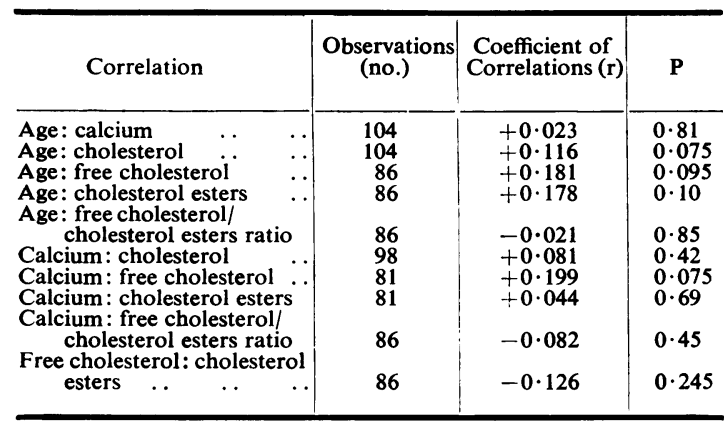

In Table 4 correlations have been calculated between age, calcium and the various cholesterol fractions.

\section{Discussion}

Serum calcium levels quoted by different authors show some variation according to the method used. There is general agreement that the level tends to be higher in infancy than in later life. Jaffe and Bodansky (1943) give a range for infancy (excluding the first week of life) of $10 \cdot 5-12.0 \mathrm{mg} . / 100 \mathrm{ml}$. By the two methods we used we found a somewhat wider range but a similar upper limit of normal.

Although there was no significant difference in the results obtained by the Kramer and Tisdall and the Trinder methods when both were carried out on random samples of adult blood it will be observed (Table 3) that at the idiopathic hypercalcaemia age period the 61 results obtained by the Kramer and Tisdall method gave a slightly higher average result $(10.3 \mathrm{mg} . / 100 \mathrm{ml}$.) than the 43 results obtained by the Trinder method $(9.9 \mathrm{mg} . / 100 \mathrm{ml}$.). The difference is significant $(P=0.01)$.

Serum cholesterol levels in the first year of life have been estimated by Hodges, Sperry and Andersen (1943) and by Rafstedt (1955). The former found a mean level of $200 \mathrm{mg} . / 100 \mathrm{ml}$. for the age period 2-6 months and $207 \mathrm{mg} . / 100 \mathrm{ml}$. for the period 7-12 months. Their results were thus similar to ours, as too was the range which they observed. Rafstedt (1955) for the period 1-12 months found a mean total cholesterol level of $130 \mathrm{mg}$. $/ 100 \mathrm{ml}$. with a range of $69-173 \mathrm{mg} . / 100 \mathrm{ml}$. Rafstedt's results for free and combined cholesterol in infancy were also lower than ours, the mean levels being $40 \mathrm{mg}$. $/ 100 \mathrm{ml}$. (range 27-66 mg./100 ml.) for free cholesterol and $90 \mathrm{mg} . / 100 \mathrm{ml}$. (range $51-132 \mathrm{mg} . / 100 \mathrm{ml}$.) for cholesterol esters. He found the mean free cholesterol/cholesterol ester ratio between 1-12 months to be 0.45 , a figure almost identical with ours. His range was narrower $(0 \cdot 31-0 \cdot 77)$ but also revealed the considerable variation in the ratio which we found.

As regards the correlations shown in Table 4 it will be observed that none is significant. The probability value of three of these correlations is less than $0 \cdot 1$, however, i.e. age: cholesterol, age: free cholesterol and calcium: free cholesterol. It is possible that with a larger number of estimations these correlations might have become significant. Positive correlation between age and cholesterol would be in keeping with the findings of György (1926) and Rafstedt (1955) (who in childhood observed a rise in total serum cholesterol with increasing age) but not with those of Hodges et al. (1943). So far as we are aware it has never been suggested that there might normally be a correlation between serum calcium and serum free cholesterol levels at this age.

\section{Summary}

A group of 110 infants aged 1-15 months has been examined.

Estimations of the serum calcium level (using two different methods) showed a range of $8 \cdot 5-12 \cdot 0 \mathrm{mg}$./ $100 \mathrm{ml}$. A difference was observed in the mean results obtained by the two methods.

Total serum cholesterol, free cholesterol and cholesterol esters were estimated and mean levels and ranges obtained.

Free cholesterol/cholesterol esters ratios, calcium $\times$ total cholesterol, calcium $\times$ free cholesterol and calcium $\times$ cholesterol esters products, and correlations between age and the cholesterol fractions, calcium and the cholesterol fractions and between the cholesterol fractions themselves have been calculated.

\section{Part II. Serum Calcium and Cholesterol Levels in Idiopathic Hypercalcaemia of Infancy}

Idiopathic hypercalcaemia of infancy presents the paediatrician with a particular problem in management and therapy. To him as well as to the biochemist, to those interested in calcium and cholesterol metabolism and to the nutritionist, the disease has even wider implications not least in its possible relationship to vitamin $\mathrm{D}$ activity and the light which it may shed on the ill-understood metabolism of this vitamin. As the incidence of idiopathic hypercalcaemia appears to be waning, opportunities for studying the disturbed biochemical relationships which occur may be diminishing.

It is generally accepted, and implied in the title, that the serum calcium level is raised in idiopathic hypercalcaemia. A raised blood cholesterol level 
TABLE 1

RESULTS OF SERUM CALCIUM AND CHOLESTEROL ESTIMATIONS CARRIED OUT ON 19 INFANTS IN THE

\begin{tabular}{|c|c|c|c|c|c|}
\hline Case & $\underset{\text { (mg.\%) }}{\text { Calcium }}$ & (mg.\%) & $\begin{array}{c}\text { Free } \\
\text { Chol. } \\
\text { (mg.\%) }\end{array}$ & $\begin{array}{l}\text { Chol. } \\
\text { Esters } \\
\text { (mg.\%) }\end{array}$ & $\begin{array}{l}\text { Free Chol. } \\
\text { Chol. Ester }\end{array}$ \\
\hline 1 & $\begin{array}{l}15 \cdot 6 \\
10 \cdot 8 \\
10 \cdot 4\end{array}$ & $\begin{array}{l}281 \\
217 \\
167\end{array}$ & 二 & 二 & $=$ \\
\hline 2 & $\begin{array}{l}12 \cdot 2 \\
11 \cdot 4 \\
11 \cdot 9 \\
10 \cdot 4 \\
11 \cdot 4\end{array}$ & $\begin{array}{l}306 \\
184 \\
186 \\
197 \\
204\end{array}$ & $\frac{\overline{106}}{\overline{52}}$ & $\frac{\overline{78}}{\overline{152}}$ & $\begin{array}{r}1 \cdot \overline{36} \\
\overline{-} \overline{342}\end{array}$ \\
\hline 3 & $\begin{array}{l}11 \cdot 2 \\
10 \cdot 0 \\
10 \cdot 3\end{array}$ & $\begin{array}{l}265 \\
194 \\
198\end{array}$ & $\overline{\overline{5}}$ & $\overline{7}$ & $\frac{\overline{7}}{357}$ \\
\hline 4 & $\begin{array}{l}16 \cdot 2 \\
15 \cdot 5 \\
12 \cdot 3 \\
12 \cdot 5 \\
14 \cdot 1 \\
14 \cdot 6 \\
13 \cdot 3 \\
10 \cdot 2\end{array}$ & $\begin{array}{l}243 \\
238 \\
145 \\
202 \\
262 \\
256 \\
237 \\
229\end{array}$ & $\begin{array}{r}\frac{141}{84} \\
127 \\
\overline{\overline{100}}\end{array}$ & $\begin{array}{l}\overline{97} \\
1 \overline{18} \\
135 \\
\overline{-} \\
129\end{array}$ & $\begin{array}{c}1 \cdot \overline{454} \\
. \overline{712} \\
.942 \\
=\overline{776}\end{array}$ \\
\hline 5 & $\begin{array}{l}12 \cdot 1 \\
13 \cdot 5 \\
13 \cdot 6 \\
10 \cdot 8 \\
11 \cdot 0 \\
10 \cdot 6\end{array}$ & $\begin{array}{l}249 \\
213 \\
158 \\
179 \\
196 \\
155\end{array}$ & $\begin{array}{r}12 \overline{123} \\
75 \\
50 \\
38\end{array}$ & $\begin{array}{r}\overline{90} \\
1 \overline{04} \\
146 \\
117\end{array}$ & $\begin{array}{c}1 \cdot \overline{367} \\
\cdot \overline{722} \\
\cdot 343 \\
\cdot 325\end{array}$ \\
\hline 6 & $\begin{array}{l}14 \cdot 8 \\
14 \cdot 0 \\
12.9 \\
10 \cdot 7\end{array}$ & $\begin{array}{l}216 \\
206 \\
175 \\
161\end{array}$ & $\begin{array}{r}152 \\
112 \\
102 \\
39\end{array}$ & $\begin{array}{r}64 \\
94 \\
73 \\
122\end{array}$ & $\begin{array}{r}2 \cdot 375 \\
1 \cdot 192 \\
1.399 \\
.320\end{array}$ \\
\hline 7 & $\begin{array}{l}12.5 \\
11.9 \\
10.8 \\
10.6 \\
13.6 \\
11.0 \\
11.0\end{array}$ & $\begin{array}{l}217 \\
133 \\
126 \\
183 \\
165 \\
230 \\
168\end{array}$ & $\begin{array}{r}100 \\
37 \\
29 \\
46 \\
41 \\
46 \\
52\end{array}$ & $\begin{array}{r}117 \\
96 \\
97 \\
137 \\
124 \\
184 \\
116\end{array}$ & $\begin{array}{l}\cdot 855 \\
\cdot 386 \\
\cdot 299 \\
\cdot 336 \\
\cdot 331 \\
\cdot 250 \\
\cdot 449\end{array}$ \\
\hline 9 & $\begin{array}{l}11 \cdot 0 \\
11.7 \\
12.0 \\
10.7 \\
10 \cdot 2 \\
10.7\end{array}$ & $\begin{array}{l}251 \\
316 \\
370 \\
320 \\
292 \\
229\end{array}$ & $\begin{array}{r}124 \\
126 \\
135 \\
102 \\
28 \\
75\end{array}$ & $\begin{array}{l}127 \\
190 \\
235 \\
218 \\
264 \\
154\end{array}$ & $\begin{array}{l}.997 \\
.664 \\
.575 \\
.468 \\
.106 \\
.487\end{array}$ \\
\hline 10 & $11 \cdot 8$ & 267 & - & - & - \\
\hline 11 & $\begin{array}{r}13.0 \\
11.8 \\
10.8 \\
10.4 \\
12.6 \\
9.5\end{array}$ & $\begin{array}{l}245 \\
179 \\
188 \\
217 \\
254 \\
198 \\
\end{array}$ & $\begin{array}{r}91 \\
67 \\
61 \\
56 \\
100 \\
75\end{array}$ & $\begin{array}{l}154 \\
112 \\
127 \\
161 \\
154 \\
123 \\
\end{array}$ & $\begin{array}{r}.591 \\
.599 \\
.481 \\
.348 \\
.650 \\
.610\end{array}$ \\
\hline 12 & $\begin{array}{l}12 \cdot 8 \\
11 \cdot 1 \\
10 \cdot 7 \\
10 \cdot 2 \\
11.9 \\
12.9\end{array}$ & $\begin{array}{l}229 \\
229 \\
176 \\
225 \\
238 \\
233 \\
\end{array}$ & $\begin{array}{r}60 \\
58 \\
63 \\
54 \\
50 \\
104 \\
\end{array}$ & $\begin{array}{l}169 \\
171 \\
113 \\
171 \\
188 \\
129 \\
\end{array}$ & $\begin{array}{l}\cdot 355 \\
\cdot 339 \\
\cdot 557 \\
\cdot 316 \\
\cdot 266 \\
\cdot 807\end{array}$ \\
\hline 13 & $12 \cdot 0$ & 320 & 130 & 190 & $\cdot 684$ \\
\hline 14 & $\begin{array}{l}12 \cdot 2 \\
10.6 \\
14 \cdot 1 \\
12 \cdot 8 \\
11.0\end{array}$ & $\begin{array}{l}250 \\
192 \\
200 \\
292 \\
158\end{array}$ & $\begin{array}{r}54 \\
58 \\
52 \\
188 \\
42 \\
\end{array}$ & $\begin{array}{l}196 \\
134 \\
148 \\
104 \\
116\end{array}$ & $\begin{array}{r}.276 \\
.433 \\
.352 \\
1.810 \\
.362\end{array}$ \\
\hline 15 & 13.4 & 210 & 63 & 147 & $\cdot 428$ \\
\hline 16 & $\begin{array}{r}13.8 \\
17.5 \\
9.9 \\
10.3 \\
\end{array}$ & $\begin{array}{l}307 \\
270 \\
160 \\
130 \\
\end{array}$ & $\frac{7}{60}$ & $\underline{\bar{Z}}$ & $\begin{array}{c}\overline{\overline{6}} \\
-\underline{66} \\
\end{array}$ \\
\hline
\end{tabular}

TABLE 1-contd.

\begin{tabular}{|c|c|c|c|c|c|}
\hline Case & $\begin{array}{l}\text { Calcium } \\
\text { (mg.\%) }\end{array}$ & $\begin{array}{l}\text { Chol. } \\
\text { (mg.\%) }\end{array}$ & $\begin{array}{l}\text { Free } \\
\text { Chol. } \\
\text { (mg.\%) }\end{array}$ & $\begin{array}{l}\text { Chol. } \\
\text { Esters } \\
\text { (mg.\%) }\end{array}$ & $\frac{\text { Free Chol. }}{\text { Chol. Ester }}$ \\
\hline 17 & $\begin{array}{l}12 \cdot 7 \\
10 \cdot 9 \\
15 \cdot 2 \\
12.4 \\
12.0\end{array}$ & $\begin{array}{l}197 \\
116 \\
181 \\
242 \\
200\end{array}$ & $\begin{array}{l}59 \\
36 \\
45 \\
71 \\
50\end{array}$ & $\begin{array}{r}138 \\
80 \\
136 \\
171 \\
150\end{array}$ & $\begin{array}{r} \\
.429 \\
.450 \\
.331 \\
.415 \\
.333\end{array}$ \\
\hline 18 & $\begin{array}{l}12 \cdot 2 \\
11 \cdot 4 \\
10 \cdot 4\end{array}$ & $\begin{array}{l}233 \\
202 \\
221\end{array}$ & $\begin{array}{r}\overline{55} \\
113\end{array}$ & $\begin{array}{l}\overline{47} \\
108\end{array}$ & $\begin{array}{r}\cdot \overline{375} \\
1 \cdot 046\end{array}$ \\
\hline 19 & $\begin{array}{l}15 \cdot 3 \\
15 \cdot 1\end{array}$ & $\begin{array}{l}285 \\
257\end{array}$ & $\begin{array}{l}85 \\
83\end{array}$ & $\begin{array}{l}200 \\
174\end{array}$ & $\begin{array}{l}.425 \\
.477\end{array}$ \\
\hline 20 & $\begin{array}{r}11.8 \\
9.6\end{array}$ & $\begin{array}{l}250 \\
240\end{array}$ & $\begin{array}{l}73 \\
55\end{array}$ & $\begin{array}{l}177 \\
185\end{array}$ & $\begin{array}{r}.413 \\
.298\end{array}$ \\
\hline Mean & $12 \cdot 08$ & $219 \cdot 4$ & $76 \cdot 4$ & $140 \cdot 6$ & .612 \\
\hline $\begin{array}{c}\text { Normal } \\
\text { mean }\end{array}$ & $10 \cdot 1$ & 194 & 57 & 137 & .453 \\
\hline
\end{tabular}

has also been a frequent finding (Lowe, Henderson, Park and McGreal, 1954; Creery and Neill, 1954; Dawson, Craig and Perera, 1954; Macdonald and Stapleton, 1955; Forfar et al., 1956).

We have studied the relationship between calcium and cholesterol in the blood in 20 infants with idiopathic hypercalcaemia, and in addition have sought to establish certain diagnostic criteria based on calcium and cholesterol levels.

\section{Serum Calcium, Serum Cholesterol and Serum} Cholesterol Fractions

Forms of treatment such as a low calcium diet and steroid therapy can significantly lower the serum calcium level in idiopathic hypercalcaemia and may have other biochemical effects. In studying the biochemical relations pertaining in the 'natural' state of the disease therefore it is necessary to exclude estimations made under any treatment which might modify these.

Table 1 gives the results in 19 cases, of serum calcium, serum cholesterol, serum free cholesterol and serum cholesterol esters estimations carried out (on the same specimen of blood) in the 'natural' state of the disease. Any treatment given had been discontinued for at least a week before the specimens were taken.

There is, as expected, a significant rise in the mean serum calcium level and in addition a significant rise in the total cholesterol and free cholesterol levels. The cholesterol esters level, on the other hand, shows no change from normal. The rise in total cholesterol is thus determined by the rise in its free cholesterol component.

The correlation co-efficients between calcium and cholesterol fractions have been calculated as shown in Table 2. There is a significant positive correlation 
TABLE 2

CORRELATIONS

\begin{tabular}{|c|c|c|c|}
\hline Correlation & $\begin{array}{c}\text { Observations } \\
\text { (no.) }\end{array}$ & $\begin{array}{l}\text { Coefficient of } \\
\text { Correlation }(r)\end{array}$ & $\mathbf{P}$ \\
\hline Calcium: total cholesterol & 75 & $+\cdot 280$ & 0.015 \\
\hline Calcium: free cholesterol & 57 & $+\cdot 361$ & $>0.01$ \\
\hline Calcium: cholesterol esters. & 57 & -.118 & $0 \cdot 37$ \\
\hline $\begin{array}{c}\text { Free cholesterol : cholesterol } \\
\text { esters } \ldots\end{array}$ & 57 & $-\cdot 150$ & $0 \cdot 26$ \\
\hline $\begin{array}{l}\text { Calcium: free cholesterol/ } \\
\text { cholesterol esters ratio. }\end{array}$ & 57 & $+\cdot 405$ & $>0.01$ \\
\hline
\end{tabular}

between calcium and both total cholesterol and free cholesterol levels; also between calcium and the free cholesterol/cholesterol esters ratio. There is no significant correlation between calcium and cholesterol esters or between free cholesterol and cholesterol esters. The critical correlation therefore is that between calcium and free cholesterol.

\section{Calcium and Cholesterol Levels in Diagnosis}

The diagnosis of idiopathic hypercalcaemia of infancy is based on clinical, radiological and especially biochemical findings. By the methods employed in our laboratory the upper limits during the age period 1-15 months for various biochemical estimations are as follows (Part I, Table 3):

\begin{tabular}{|c|c|c|}
\hline Estimation & Mean + S.D. $\times 2 \cdot 57$ & Mean + S.D. $\times 2$ \\
\hline $\begin{array}{l}\text { Serum calcium } \\
\text { Serum cholesterol } \ldots \\
\text { Serum free cholesteroi } \\
\text { Serum cholesterol esters } \\
\text { Calcium } \times \text { cholesterol } \\
\text { Calcium } \times \text { free cholesterol }\end{array}$ & $\begin{array}{c}12.0 \mathrm{mg} . \% \\
292 \mathrm{mg} \% \% \\
105 \mathrm{mg} . \% \\
223 \mathrm{mg} \% \\
2,980 \\
1,110\end{array}$ & $\begin{array}{l}(11 \cdot 6) \mathrm{mg} . \% \\
(270) \mathrm{mg} . \% \\
(94) \mathrm{mg} . \% \\
(204) \mathrm{mg} \% \% \\
(2,753) \\
(993)\end{array}$ \\
\hline
\end{tabular}

It has been suggested previously (Forfar et al., 1956) that as both serum calcium and cholesterol tend to be raised in idiopathic hypercalcaemia the use of their product might be of value in diagnosis where neither is in itself raised above the upper limit of normal. In addition to the basic estimations of calcium and cholesterol we have used these products as diagnostic criteria as shown in Table 3.

This Table presents the results of simultaneous (on the same specimen of blood) serum calcium, cholesterol and free cholesterol estimations carried out on 131 blood samples at all stages of the disease. It also gives the highest serum calcium level obtained at any time.

In 15 of the 20 cases there would be no doubt on biochemical grounds of the diagnosis of idiopathic hypercalcaemia. Stapleton and Evans (1955) have put the diagnostic level at above $12.5 \mathrm{mg} . / 100 \mathrm{ml}$.
These fifteen cases show serum calcium levels greater than this. Among them it will be observed that in Cases 2 and 5 the serum free cholesterol level and the calcium $\times$ free cholesterol product were both raised at a time when the serum calcium level was within normal limits, and in Case 19 that total cholesterol and the calcium $\times$ cholesterol product on one occasion, and the free cholesterol and calcium $\times$ free cholesterol product on another were raised in the presence of a normal calcium level. Thus the cholesterol and free cholesterol levels and/or their products with calcium may be diagnostic when the serum calcium level itself is not significantly raised.

Turning to the other five cases it will be observed that in two (Cases 10 and 18) the highest serum calcium level was greater than $12.0 \mathrm{mg} . / 100 \mathrm{ml}$, i.e. above our upper limit of normal, and that in addition the calcium $\times$ cholesterol product in Case 10 and the free cholesterol level and calcium $\times$ free cholesterol product in Case 18 were above normal.

In two of the remaining three cases the highest serum calcium level reached was $12.0 \mathrm{mg} . / 100 \mathrm{ml}$. In both of these (Cases 9 and 13) the serum cholesterol level, serum free cholesterol, calcium $\times$ cholesterol product and calcium $\times$ free cholesterol product were raised.

The remaining case is Case 3 whose highest serum calcium level was $11.2 \mathrm{mg} . / 100 \mathrm{ml}$. His calcium $\times$ cholesterol product reached 2,968 , practically the upper limit of normal. He suffered from an illness which, although comparatively short-lived and mild, was clinically suggestive of idiopathic hypercalcaemia and he was the identical twin of Case 2, who undoubtedly suffered from this disease. His serum calcium fell as he recovered.

Serum cholesterol, serum free cholesterol and their products with serum calcium are thus of value in the diagnosis of idiopathic hypercalcaemia where the calcium level itself does not establish diagnosis or on occasion when the serum calcium level has been lowered by treatment (as indicated in Table 3). With a low calcium diet, for instance, the serum calcium level may fall quickly but cholesterol and free cholesterol and their products with calcium may still remain elevated. A raised total or free cholesterol level is also confirmatory of a raised calcium level in this disease.

Of the 131 blood samples taken, 59 were positive in respect of one or more of the five biochemical criteria, yet in $14(24 \%)$ of these positive samples the serum calcium level was not above normal. In four, total cholesterol, free cholesterol, calcium $\times$ cholesterol and calcium $\times$ free cholesterol conferred positivity; in one, free cholesterol, calcium $\times$ cholesterol and calcium $\times$ free cholesterol; in two, 
TABLE 3

CALCIUM, CHOLESTEROL AND FREE CHOLESTEROL ESTIMATIONS FOR 131 BLOOD SAMPLES FROM 20 CASES OF IDIOPATHIC HYPERCALCAEMIA

\begin{tabular}{|c|c|c|c|c|c|c|}
\hline $\begin{array}{c}\text { Case } \\
\text { (Highest Serum } \\
\text { Calcium } \\
\text { (mg.\%)) }\end{array}$ & $\begin{array}{c}\text { Serum Calcium } \\
(\mathrm{mg} . \%)\end{array}$ & $\mid \begin{array}{c}\text { Serum Cholesterol } \\
(\mathrm{mg} \%)\end{array}$ & $\begin{array}{l}\text { Serum Free } \\
\text { Cholesterol } \\
(\mathrm{mg} . \%)\end{array}$ & $\begin{array}{l}\text { Calcium } \times \\
\text { Cholesterol }\end{array}$ & $\underset{\text { Free Cholesterol }}{\text { Calcium } x}$ & Treatment \\
\hline$(16 \cdot 4)$ & $\begin{array}{l}15 \cdot 6 \\
10 \cdot 8 \\
10 \cdot 4\end{array}$ & $\begin{array}{l}281 \\
217 \\
167\end{array}$ & $=$ & $\begin{array}{l}4,384 \\
2,344 \\
1,736\end{array}$ & = & \\
\hline $\begin{array}{c}2 \\
\left(15^{2} \cdot 6\right)\end{array}$ & $\begin{array}{l}12.2 \\
11.4 \\
11.9 \\
11 \cdot 5 \\
15 \cdot 1 \\
10.4 \\
11.4\end{array}$ & $\begin{array}{l}306 \\
184 \\
186 \\
156 \\
206 \\
197 \\
204\end{array}$ & $\begin{array}{l}\overline{106} \\
\bar{z} \\
\overline{52}\end{array}$ & $\begin{array}{l}\mathbf{3 , 7 3 2} \\
2,095 \\
2,212 \\
1,793 \\
\mathbf{3}, 110 \\
2,049 \\
2,324\end{array}$ & $\begin{array}{l}\overline{1,207} \\
\overline{=} \\
\overline{593}\end{array}$ & \\
\hline $\begin{array}{c}3 \\
(11 \cdot 2)\end{array}$ & $\begin{array}{l}11 \cdot 2 \\
10 \cdot 0 \\
10 \cdot 3\end{array}$ & $\begin{array}{l}265 \\
194 \\
198\end{array}$ & $\overline{52}$ & $\begin{array}{l}\mathbf{2 , 9 6 8} \\
1,940 \\
2,039\end{array}$ & $\overline{534}$ & \\
\hline $\begin{array}{c}4 \\
(16 \cdot 2)\end{array}$ & $\begin{array}{l}16 \cdot 2 \\
15.5 \\
12.3 \\
13.4 \\
15.5 \\
12.5 \\
14.1 \\
14.6 \\
10.7 \\
13 \cdot 3 \\
10.2\end{array}$ & $\begin{array}{l}243 \\
238 \\
145 \\
226 \\
261 \\
202 \\
262 \\
256 \\
197 \\
237 \\
229\end{array}$ & $\begin{array}{r}1 \overline{41} \\
\overline{\overline{84}} \\
127 \\
\overline{=} \\
\overline{100}\end{array}$ & $\begin{array}{l}\mathbf{3 , 9 3 6} \\
\mathbf{3 , 6 8 7} \\
\mathbf{1}, 783 \\
\mathbf{3 , 0 2 6} \\
\mathbf{4}, 047 \\
2,526 \\
\mathbf{3 , 6 9 2} \\
\mathbf{3 , 7 3 5} \\
\mathbf{2 , 1 0 7} \\
\mathbf{3 , 1 5 1} \\
\mathbf{2 , 3 3 4}\end{array}$ & $\begin{array}{c}2, \overline{185} \\
\overline{=} \\
\overline{1,050} \\
1, \overline{791} \\
\overline{=} \\
\overline{1,020}\end{array}$ & Cort. \\
\hline $\begin{array}{c}5 \\
(13 \cdot 6)\end{array}$ & $\begin{array}{r}12.1 \\
13.5 \\
13.6 \\
9.8 \\
10.8 \\
11.4 \\
9.8 \\
11.0 \\
10.6\end{array}$ & $\begin{array}{l}249 \\
213 \\
158 \\
155 \\
179 \\
206 \\
260 \\
196 \\
155\end{array}$ & $\begin{array}{r}12 \overline{123} \\
\overline{71} \\
75 \\
141 \\
136 \\
50 \\
38\end{array}$ & $\begin{array}{l}\mathbf{3 , 0 1 3} \\
2,876 \\
2,148 \\
1,520 \\
1,932 \\
2,346 \\
2,546 \\
2,156 \\
1,643\end{array}$ & $\begin{array}{r}1, \overline{661} \\
\overline{696} \\
810 \\
1,608 \\
1,333 \\
550 \\
404\end{array}$ & $\begin{array}{l}\text { Pred. } \\
\text { LCD } \\
\text { LCD } \\
\text { LCD }\end{array}$ \\
\hline $\begin{array}{c}6 \\
(14 \cdot 8)\end{array}$ & $\begin{array}{r}14 \cdot 8 \\
14.0 \\
12.9 \\
12.2 \\
10.0 \\
9.7 \\
9.8 \\
10.5 \\
9.7 \\
10.6 \\
10 \cdot 1 \\
10.7\end{array}$ & $\begin{array}{l}216 \\
206 \\
175 \\
171 \\
196 \\
135 \\
150 \\
158 \\
162 \\
166 \\
240 \\
161\end{array}$ & $\begin{array}{c}152 \\
112 \\
102 \\
85 \\
54 \\
45 \\
50 \\
50 \\
46 \\
30 \\
38 \\
39\end{array}$ & $\begin{array}{l}\mathbf{3 , 1 9 8} \\
2,881 \\
2,257 \\
2,085 \\
1,960 \\
1,310 \\
1,470 \\
1,660 \\
1,570 \\
1,759 \\
2,423 \\
1,722\end{array}$ & $\begin{array}{r}\mathbf{2 , 2 5 0} \\
1,567 \\
1,315 \\
1,037 \\
540 \\
437 \\
490 \\
525 \\
446 \\
318 \\
384 \\
417\end{array}$ & $\begin{array}{l}\text { LCD } \\
\text { LCD + Pred. } \\
\text { LCD } \\
\text { LCD + Pred. } \\
\text { LCD + Pred. }\end{array}$ \\
\hline $\begin{array}{c}7 \\
(13 \cdot 6)\end{array}$ & $\begin{array}{l}12.5 \\
11.9 \\
10.8 \\
10.6 \\
10.6 \\
13.6 \\
11.0 \\
11.0\end{array}$ & $\begin{array}{l}217 \\
133 \\
126 \\
192 \\
183 \\
165 \\
230 \\
168\end{array}$ & $\begin{array}{r}100 \\
37 \\
29 \\
50 \\
46 \\
41 \\
46 \\
52\end{array}$ & $\begin{array}{l}2,711 \\
1,582 \\
1,361 \\
2,035 \\
1,939 \\
2,243 \\
2,530 \\
1,847\end{array}$ & $\begin{array}{r}1,250 \\
440 \\
313 \\
530 \\
487 \\
557 \\
506 \\
572\end{array}$ & Pred. \\
\hline $\begin{array}{c}8 \\
(17 \cdot 0) \\
\end{array}$ & $\begin{array}{l}15 \cdot 1 \\
10 \cdot 9 \\
\end{array}$ & $\begin{array}{l}247 \\
172 \\
\end{array}$ & $\begin{array}{l}88 \\
86\end{array}$ & $\begin{array}{l}3,728 \\
1,874 \\
\end{array}$ & $\begin{array}{r}1,328 \\
937\end{array}$ & LCD \\
\hline$\stackrel{9}{9}$ & $\begin{array}{r}11.0 \\
11.7 \\
12.0 \\
10.7 \\
10.2 \\
10.4 \\
9.9 \\
10.7 \\
11.4 \\
9.6 \\
10.3\end{array}$ & $\begin{array}{l}251 \\
316 \\
370 \\
320 \\
292 \\
283 \\
254 \\
229 \\
286 \\
342 \\
272\end{array}$ & $\begin{array}{r}124 \\
126 \\
135 \\
102 \\
28 \\
58 \\
81 \\
75 \\
142 \\
131 \\
73\end{array}$ & $\begin{array}{l}\mathbf{2 , 7 6 0} \\
\mathbf{3}, 700 \\
4,438 \\
\mathbf{3 , 4 2 4} \\
2,975 \\
2,941 \\
2,515 \\
\mathbf{2 , 4 4 8} \\
\mathbf{3 , 2 5 9} \\
\mathbf{3 , 2 8 2} \\
\mathbf{2 , 8 3 2}\end{array}$ & $\begin{array}{r}1,364 \\
1,475 \\
1,620 \\
1,091 \\
286 \\
603 \\
802 \\
802 \\
1,618 \\
1,257 \\
741\end{array}$ & $\begin{array}{l}\text { LCD + Cort. } \\
\text { LCD + Cort. } \\
\text { LCD } \\
\text { LCD } \\
\text { LCD } \\
\text { LCD }\end{array}$ \\
\hline $\begin{array}{c}10 \\
(12 \cdot 2)\end{array}$ & $\begin{array}{l}11 \cdot 8 \\
10 \cdot 4\end{array}$ & $\begin{array}{l}267 \\
250\end{array}$ & 60 & $\begin{array}{l}3,150 \\
2,600\end{array}$ & $\overline{624}$ & LCD \\
\hline
\end{tabular}


TABLE 3-contd.

\begin{tabular}{|c|c|c|c|c|c|c|}
\hline $\begin{array}{c}\text { Case } \\
\begin{array}{l}\text { (Highest Serum } \\
\text { Calcium } \\
\text { (mg.\%) }\end{array} \\
\end{array}$ & $\begin{array}{c}\text { Serum Calcium } \\
\text { (mg. \%) }\end{array}$ & $\begin{array}{c}\text { Serum Cholesterol } \\
(\mathrm{mg} . \%)\end{array}$ & $\begin{array}{c}\text { Serum Free } \\
\text { Cholesterol } \\
\text { (mg.\%) }\end{array}$ & $\underset{\text { Cholesterol }}{\text { Calcium }} \times$ & $\begin{array}{c}\text { Calcium } \times \\
\text { Free Cholesterol }\end{array}$ & Treatment \\
\hline $\begin{array}{c}11 \\
(13 \cdot 0)\end{array}$ & $\begin{array}{r}13.0 \\
11.8 \\
10.8 \\
10.4 \\
12.6 \\
10.0 \\
9.5 \\
\end{array}$ & $\begin{array}{l}245 \\
179 \\
188 \\
217 \\
254 \\
276 \\
198\end{array}$ & $\begin{array}{r}91 \\
67 \\
61 \\
56 \\
100 \\
83 \\
75 \\
\end{array}$ & $\begin{array}{l}3,184 \\
2,112 \\
2,029 \\
2,257 \\
3,198 \\
2,760 \\
1,882\end{array}$ & $\begin{array}{r}1.182 \\
791 \\
659 \\
582 \\
1,260 \\
830 \\
713 \\
\end{array}$ & LCD \\
\hline $\begin{array}{c}12 \\
(12 \cdot 9)\end{array}$ & $\begin{array}{l}12.8 \\
11.1 \\
10.7 \\
10.2 \\
11.9 \\
10.4 \\
12.9 \\
\end{array}$ & $\begin{array}{l}229 \\
229 \\
176 \\
225 \\
236 \\
267 \\
233\end{array}$ & $\begin{array}{r}60 \\
58 \\
63 \\
54 \\
50 \\
38 \\
104 \\
\end{array}$ & $\begin{array}{l}2,928 \\
2,540 \\
1,882 \\
2,295 \\
2,832 \\
2,777 \\
\mathbf{3 , 0 0 1}\end{array}$ & $\begin{array}{r}768 \\
644 \\
674 \\
551 \\
595 \\
395 \\
1,340\end{array}$ & \\
\hline $\begin{array}{c}13 \\
(12 \cdot 0)\end{array}$ & $\begin{array}{l}12 \cdot 0 \\
10 \cdot 1\end{array}$ & $\begin{array}{l}320 \\
242\end{array}$ & $\begin{array}{r}130 \\
46\end{array}$ & $\begin{array}{l}3,840 \\
2,443\end{array}$ & $\begin{array}{r}1,560 \\
464\end{array}$ & LCD \\
\hline $\begin{array}{c}14 \\
(14 \cdot 1)\end{array}$ & $\begin{array}{l}12 \cdot 2 \\
10 \cdot 6 \\
14 \cdot 1 \\
12 \cdot 8 \\
11 \cdot 0 \\
10 \cdot 5\end{array}$ & $\begin{array}{l}250 \\
192 \\
200 \\
292 \\
158 \\
198\end{array}$ & $\begin{array}{r}54 \\
58 \\
52 \\
188 \\
42 \\
94 \\
\end{array}$ & $\begin{array}{l}3,050 \\
2,034 \\
2,820 \\
3,738 \\
1,738 \\
2,078\end{array}$ & $\begin{array}{r}659 \\
615 \\
733 \\
2,406 \\
464 \\
987\end{array}$ & LCD \\
\hline $\begin{array}{c}15 \\
(13 \cdot 4)\end{array}$ & $13 \cdot 4$ & 210 & 63 & 2,812 & 844 & \\
\hline $\begin{array}{l}16 \\
(17 \cdot 5)\end{array}$ & $\begin{array}{r}13.8 \\
17.5 \\
11.4 \\
11.4 \\
11.5 \\
15.8 \\
16.6 \\
14.9 \\
16.6 \\
12.3 \\
12.0 \\
10.2 \\
9.9 \\
10 \cdot 3\end{array}$ & $\begin{array}{l}307 \\
270 \\
220 \\
156 \\
146 \\
160 \\
163 \\
150 \\
140 \\
156 \\
138 \\
190 \\
160 \\
130\end{array}$ & $\begin{array}{l}= \\
\bar{Z} \\
\overline{50} \\
\overline{63} \\
50 \\
45 \\
61 \\
50 \\
55 \\
60 \\
-\end{array}$ & $\begin{array}{l}4,232 \\
4,722 \\
2,507 \\
1,778 \\
1,676 \\
2,527 \\
2,704 \\
2,234 \\
2,324 \\
1,919 \\
1,654 \\
1,936 \\
1,584 \\
1,337 \\
\end{array}$ & $\begin{array}{c}\bar{Z} \\
\bar{z} \\
\overline{575} \\
\overline{1} \\
1, \overline{045} \\
745 \\
747 \\
750 \\
600 \\
561 \\
594 \\
\end{array}$ & $\begin{array}{l}\text { LCD } \\
\text { LCD } \\
\\
\text { LCD } \\
\text { LCD } \\
\text { LCD } \\
\text { LCD } \\
\text { LCD }\end{array}$ \\
\hline $\begin{array}{c}17 \\
(15 \cdot 2)\end{array}$ & $\begin{array}{l}12 \cdot 7 \\
10 \cdot 9 \\
15 \cdot 2 \\
12 \cdot 4 \\
12 \cdot 0 \\
10 \cdot 9 \\
10 \cdot 4 \\
10 \cdot 3 \\
10 \cdot 1\end{array}$ & $\begin{array}{l}197 \\
116 \\
181 \\
242 \\
200 \\
174 \\
192 \\
225 \\
232\end{array}$ & $\begin{array}{l}59 \\
36 \\
45 \\
71 \\
50 \\
50 \\
96 \\
98 \\
\end{array}$ & $\begin{array}{l}2,501 \\
1,263 \\
2,748 \\
3,000 \\
2,400 \\
1,896 \\
1,996 \\
2,317 \\
2,343 \\
\end{array}$ & $\begin{array}{l}749 \\
392 \\
684 \\
880 \\
600 \\
520 \\
989 \\
990 \\
\end{array}$ & $\begin{array}{l}\text { LCD } \\
\text { LCD } \\
\text { LCD } \\
\text { LCD } \\
\end{array}$ \\
\hline $\begin{array}{c}18 \\
(12 \cdot 2)\end{array}$ & $\begin{array}{l}12 \cdot 2 \\
11.4 \\
10 \cdot 4 \\
\end{array}$ & $\begin{array}{l}233 \\
202 \\
221\end{array}$ & $\begin{array}{r}\overline{55} \\
113\end{array}$ & $\begin{array}{l}2,840 \\
2,302 \\
2,297\end{array}$ & $\begin{array}{r}\overline{627} \\
1,175\end{array}$ & \\
\hline $\begin{array}{c}19 \\
(15 \cdot 3)\end{array}$ & $\begin{array}{r}15 \cdot 3 \\
15 \cdot 1 \\
12 \cdot 1 \\
9 \cdot 4 \\
12 \cdot 0 \\
12 \cdot 1 \\
11 \cdot 2 \\
12 \cdot 0 \\
10 \cdot 8 \\
11 \cdot 2 \\
10 \cdot 0 \\
11 \cdot 0\end{array}$ & $\begin{array}{l}285 \\
257 \\
178 \\
283 \\
215 \\
207 \\
172 \\
320 \\
234 \\
250 \\
228 \\
-\end{array}$ & $\begin{array}{r}85 \\
83 \\
50 \\
158 \\
50 \\
45 \\
36 \\
68 \\
53 \\
65 \\
78\end{array}$ & $\begin{array}{c}\mathbf{4 , 3 5 8} \\
\mathbf{3 , 8 8 0} \\
\mathbf{2 , 1 5 4} \\
2,660 \\
2,580 \\
2,503 \\
1,925 \\
\mathbf{3 , 8 4 0} \\
2,525 \\
2,800 \\
2,280 \\
-\end{array}$ & $\begin{array}{r}1,299 \\
1,252 \\
605 \\
1,484 \\
600 \\
545 \\
403 \\
734 \\
734 \\
593 \\
650 \\
858\end{array}$ & $\begin{array}{l}\text { LCD } \\
\text { LCD } \\
\text { LCD } \\
\text { LCD+Pred. } \\
\text { LCD + Pred. } \\
\text { LCD } \\
\text { LCD } \\
\text { LCD } \\
\text { LCD }\end{array}$ \\
\hline $\begin{array}{c}20 \\
(13 \cdot 4)\end{array}$ & $\begin{array}{r}11 \cdot 8 \\
9 \cdot 6\end{array}$ & $\begin{array}{l}250 \\
240\end{array}$ & $\begin{array}{l}73 \\
55\end{array}$ & $\begin{array}{l}2,950 \\
2,302\end{array}$ & $\begin{array}{l}862 \\
528\end{array}$ & \\
\hline
\end{tabular}

LCD $=$ low calcium diet $;$ Cort. $=$ cortisone; Pred. $=$ prednisolone

cholesterol and calcium $\times$ cholesterol; in six, free cholesterol and calcium $\times$ free cholesterol, and in one, calcium $\times$ cholesterol alone.

We have purposely set our upper limits of normal high at mean + standard deviation $\times 2 \cdot 57(P=0 \cdot 01)$.
We may in fact have set the limit too high. Had we used the customary upper limit of normal, mean + standard deviation $\times 2$ (as also given above), a considerably greater number of values in Table 3 would have been diagnostic. 


\section{Discussion}

One of the most fascinating aspects of idiopathic hypercalcaemia concerns aetiology and possible relationship to vitamin $\mathrm{D}$ administration. Many reports testify that the dosage of vitamin $\mathrm{D}$ has often been no greater than that considered optimal and seldom greater than the average dosage received by the vast majority of healthy infants. The dosage has been in no way comparable to that known to cause frank vitamin $\mathrm{D}$ poisoning. Lacking evidence of gross overdosage the concept of undue hypersensitivity to vitamin D has been put forward by Lightwood (1952) and supported by Lowe et al. (1954), Bonham Carter, Dent, Fowler and Harper (1955) and Morgan, Mitchell, Stowers and Thomson (1956). On the other hand, administration of increased amounts of vitamin D to infants suffering from idiopathic hypercalcaemia may not cause any worsening or significant biochemical change (Creery and Neill, 1954; Forfar et al., 1956).

Vitamin $D$ poisoning in the adult may cause hypercholesterolaemia but the scanty evidence available on vitamin $D$ poisoning in infancy suggests that at that age period it does not do so. Fanconi and de Chastonay (1950) found that hypocholesterolaemia occurred in three infants aged $9 \frac{1}{2}, 6$ and 11 months who had received grossly excessive dosages of vitamin $\mathrm{D}$, but hypercholesterolaemia occurred in a $4 \frac{1}{2}$-year-old child in similar circumstances. These authors comment particularly on this age distinction. Jelke (1946) found no hypercholesterolaemia in vitamin $D$ poisoning in an infant.

In view of the apparently increased vitamin D-like activity in idiopathic hypercalcaemia and the fact that some cholesterol derivatives have a vitamin Dlike effect (e.g. vitamin $D_{3}$ is derived from 7-dehydrocholesterol), it has been suggested that this disease may be related primarily to a disorder of cholesterol metabolism with excess production of a cholesterol derivative with a vitamin D-like effect (Forfar et al., 1956). The recent work of Fellers and Schwartz (1958) has lent some support to this view. They estimated the vitamin D-like activity in two severe cases of idiopathic hypercalcaemia by bio-assay methods and found increased activity which persisted unchanged for periods up to 17 months after all exogenous vitamin $\mathrm{D}$ had been withdrawn. The degree of activity was greater than that found in two children receiving 100,000 units of vitamin $D$ daily.

Whether the synthesis or storage of a provitamin can occur in the human is uncertain but it can certainly occur in animals. Glover, Glover and Morton (1952) have shown that provitamin $D_{3}$ can be found in the tissues of certain animals even when the animals are fed on a practically sterol-free diet.
They concluded that the animal could synthesize provitamin D from cholesterol. In the guinea-pig infection of the liver with Pasteurella pseudotuberculosis was found to be associated with an increased concentration of provitamin in the intestinal mucosa, an interesting observation in view of the possible role of infection in idiopathic hypercalcaemia.

While activation of vitamin precursors, such as 7-dehydrocholesterol and ergosterol, is readily effected by irradiation, chemical activation is theoretically possible. Raoul, Le Boulch, Baron, Bazier and Guerilot-Vinet (1956) showed that cholesterol can be transformed to antirachitic compounds by a variety of natural earth, floridin. It has been suggested by Forfar (1958) that calciferol may act as a chemical activator in this disease; that apart from its own vitamin $D$ effect calciferol may activate endogenous vitamin $\mathbf{D}$ precursors present in excess. A hypothesis of this sort would explain many of the features of idiopathic hypercalcaemia of infancy. Infants with an increased formation of endogenous vitamin D precursor would be those susceptible. Primarily, activation of that vitamin precursor would cause the disease. The dosage of exogenous vitamin $\mathrm{D}$ required to do this may not be large and dosage in excess of the activating amount will presumably merely aggravate the disease. This concept explains the comparatively small intake of vitamin D with which idiopathic hypercalcaemia may be associated and also the absence of a direct quantitative relationship between intake of vitamin $D$ and severity of the disease. This theory could also explain the prolonged vitamin D-like activity which frequently persists in idiopathic hypercalcaemia after withdrawal of all vitamin D. As a corollary, variations in endogenous vitamin D precursor formation might explain the varying vitamin $D$ needs in infancy to which Follis, Park and Jackson (1953) have drawn attention. Infants with low endogenous formation would be those liable to develop rickets, infants with high formation those requiring little or no exogenous vitamin $D$. It may be not without relevance that hypothyroid children, in whom there is also a disorder of cholesterol metabolism with a tendency to hypercholesterolaemia, are peculiarly resistant to rickets and peculiarly sensitive to vitamin D (Fanconi, 1956). If indeed idiopathic hypercalcaemia is associated with the use of the synthetic substance calciferol, as opposed to natural vitamin $D$, the advisability of using calciferol in place of natural vitamin may need further consideration.

It is doubtful whether idiopathic hypercalcaemia exists in two distinct types, the severe and the mild, or whether the difference is merely one of degree. 
Reviewing the literature, Daeschner and Daeschner (1957) reported that the average interval between the time of onset of symptoms and diagnosis in the severe type of the disease was 13 months. In $\mathbf{5 2}$ reported cases of the mild type we have found that the corresponding average interval was less than six months. It seems possible that the severe type of the disease results essentially from delay in diagnosis. The use of total cholesterol and free cholesterol estimations in diagnosis in the manner outlined above may allow earlier positive recognition of the disease and the earlier institution of treatment and may allow recognition where diagnosis cannot be made on the basis of serum calcium estimations alone. Earlier diagnosis and treatment will presumably reduce the risks of mental retardation and permanent renal damage which accompany this disease. The use of the cholesterol factors may also be of some value in assessing progress during treatment.

\section{Summary}

An assessment has been made of the calcium, cholesterol, free cholesterol and cholesterol esters fractions of serum in 19 cases of idiopathic hypercalcaemia examined in the 'natural' (untreated) state of the disease.

Serum calcium, cholesterol and free cholesterol levels are significantly raised in the disease. Serum cholesterol esters level is not raised.

Calculation of correlation coefficients shows that there is a significant positive correlation between serum calcium, cholesterol and free cholesterol levels. The critical correlation is that between serum calcium and serum free cholesterol.

The results of simultaneous estimations of serum calcium, cholesterol and free cholesterol at all stages of the disease are presented. The role of the cholesterol fractions on their own and as a product with serum calcium in increasing the accuracy of diagnosis in idiopathic hypercalcaemia is indicated.

Disturbances of cholesterol metabolism are discussed in the light of the possible relationship of the condition to vitamin $\mathrm{D}$, and an aetiological hypothesis is elaborated.

\section{Part III. Blood Citrate Levels and Urinary Citrate Output in Idiopathic Hypercalcaemia of Infancy}

Citrate occurs in high concentration in bone, probably 50-100 times the concentration found in other tissues (Dickens, 1941; Dixon, 1956). The general consensus of opinion is that citrate is actively involved in the metabolism of bone. Harrison (1954), for instance, considers that the serum citrate level may be related to the activity of those metabolic processes in skeleton which actively destroy bone matrix and dissolve bone salts. Armstrong and Singer (1956), on the other hand, consider that the concentration of citrate in bone may be merely adventitious, body citrate being attracted to bone in virtue of the peculiar chemical and physical character of the latter.

We have made observations on the serum citrate levels and urinary citrate output at various stages of idiopathic hypercalcaemia. In addition we have assessed the normal serum citrate level in a group of 32 unaffected infants aged 2-15 months.

\section{Methods}

The method employed for the determination of citrate in serum and urine was predominantly that of Taylor (1953). Untreated urine and trichloracetic extract of serum were used. Citrate was converted into pentabromoacetone (bromide/bromate/vanadate reagent plus sulphuric acid). After neutralization of the reaction mixture with ferrous sulphate, the pentabromoacetone was extracted with petroleum ether. A yellow colour was produced in the presence of a solution of borax and thiourea (Snell and Snell, 1953), the final estimation being made colorimetrically. Urine for citrate analysis was collected in a bottle containing dilute sulphuric acid to prevent loss of citrate.

Serum calcium was determined by the method of Trinder (1957).

\section{Results}

Serum Citrate Levels. The results of 32 serum citrate estimations carried out on controls, aged 2-15 months, are shown in Table 1. Serum calcium was estimated coincidentally with serum citrate. The mean serum citrate level was $2.4 \mathrm{mg} . / 100 \mathrm{ml}$. and the range (mean \pm S.D. $\times 2) 1 \cdot 2-3 \cdot 5 \mathrm{mg} . / 100 \mathrm{ml}$. For the age range 2 months -2 years Harrison and Harrison (1952) found the mean serum citrate level to be $2.5 \mathrm{mg} . / 100 \mathrm{ml}$. with range $2.0-3.4 \mathrm{mg}$./ $100 \mathrm{ml}$. There is no evidence of correlation between calcium and citrate levels (correlation coefficient $=-0 \cdot 04)$.

The results of 28 coincident estimations of serum calcium and serum citrate at various stages of the disease in 11 cases of idiopathic hypercalcaemia in the 'natural' (see Part II) state are shown in Table 2. It will be seen that the mean citrate level is not significantly different from normal. The range however is wider than normal, being (mean \pm S.D. $\times 2$ ) $0.6-4.8 \mathrm{mg} . / 100 \mathrm{ml}$. Study of individual cases (the levels are in chronological order for individual cases) suggests that the serum citrate level is low in the acute phase of the disease and high in the recovery phase. Indeed the mean serum citrate level on the 10 occasions when the serum calcium was $11.6 \mathrm{mg}$./ 
TABLE 1

SER UM CALCIUM AND CITRATE LEVELS IN 32 CONTROL INFANTS AGED 2-15 MONTHS

\begin{tabular}{|c|c|c|}
\hline $\begin{array}{c}\text { Age } \\
\text { (mth.) }\end{array}$ & $\begin{array}{c}\text { Serum Calcium } \\
(\mathrm{mg} \% \%)\end{array}$ & $\begin{array}{c}\text { Serum Citrate } \\
(\mathrm{mg} . \%)\end{array}$ \\
\hline $\begin{array}{r}9 \\
5 \frac{1}{2} \\
12 \\
15 \\
6 \\
13 \\
7 \\
4 \\
2 \\
15 \\
3 \\
6 \\
12 \\
3 \frac{1}{2} \\
15 \\
12 \\
9 \\
9 \\
9 \\
2 \\
7 \\
5 \\
2 \\
13 \\
5 \frac{1}{2} \\
8 \\
13 \\
4 \\
4 \\
4\end{array}$ & $\begin{array}{r}9 \cdot 4 \\
9 \cdot 7 \\
10 \cdot 4 \\
10 \cdot 2 \\
11 \cdot 2 \\
8 \cdot 8 \\
10 \cdot 0 \\
10 \cdot 4 \\
10 \cdot 3 \\
10 \cdot 3 \\
9 \cdot 5 \\
10 \cdot 2 \\
10 \cdot 3 \\
10.9 \\
10 \cdot 1 \\
10 \cdot 6 \\
10 \cdot 7 \\
9 \cdot 5 \\
10 \cdot 7 \\
10 \cdot 2 \\
9 \cdot 6 \\
10 \cdot 7 \\
9.4 \\
8 \cdot 9 \\
9 \cdot 6 \\
10 \cdot 1 \\
10 \cdot 3 \\
9.9 \\
9.3 \\
9.9 \\
9 \cdot 8 \\
11 \cdot 1\end{array}$ & $\begin{array}{l}2 \cdot 0 \\
1 \cdot 8 \\
2 \cdot 4 \\
2 \cdot 8 \\
2 \cdot 8 \\
2 \cdot 4 \\
3 \cdot 5 \\
2 \cdot 0 \\
2 \cdot 1 \\
1 \cdot 8 \\
2 \cdot 3 \\
2 \cdot 0 \\
2 \cdot 1 \\
2 \cdot 1 \\
2 \cdot 0 \\
2 \cdot 4 \\
2 \cdot 6 \\
1 \cdot 6 \\
3 \cdot 0 \\
2 \cdot 2 \\
3 \cdot 4 \\
2 \cdot 5 \\
0 \cdot 8 \\
3 \cdot 3 \\
3 \cdot 4 \\
2 \cdot 5 \\
1 \cdot 9 \\
2 \cdot 5 \\
1 \cdot 6 \\
2 \cdot 3 \\
2 \cdot 9 \\
1 \cdot 6\end{array}$ \\
\hline Mean & $10 \cdot 1$ & $2 \cdot 35$ \\
\hline
\end{tabular}

$100 \mathrm{ml}$. or above (we have taken $11.6 \mathrm{mg} . / 100 \mathrm{ml}$. as this is the upper limit of normal for the method of calcium estimation we were using) was $1 \cdot 8$, and on the 18 occasions when the serum calcium level was below $11.6 \mathrm{mg}$. $/ 100 \mathrm{ml}$. it was $3.1 \mathrm{mg} . / 100 \mathrm{ml}$.

The correlation coefficient between serum calcium and serum citrate levels for the results shown in Table 2 is $-0.732(P=>0.01)$. There is thus a highly significant negative correlation between calcium and citrate levels in idiopathic hypercalcaemia.

In Fig. 1 the results of all serum citrate levels in 14 cases before, during and after treatment have been charted. Points plotted along the time abscissa have been dated from time of admission to hospital with the object of indicating the pattern of citrate level during the course of the disease. As the early cases were treated less efficiently than the later ones and as some cases were already undergoing some spontaneous improvement by the time of admission to hospital, this method of representing the course of the disease is of necessity somewhat artificial. It does again suggest, however, that the serum citrate level tends to be low in the early stages of the disease and rises with improvement. Recovery indeed seems to be associated with a rise up to or beyond the upper limit of normal with a later fall to average levels.

Urinary Citrate. Seventeen estimations of urinary
TABLE 2

SERUM CALCIUM AND CITRATE LEVELS IN IDIOPATHIC HYPERCALCAEMIA

\begin{tabular}{|c|c|}
\hline $\begin{array}{c}\text { Serum Calcium } \\
(\mathrm{mg} . \%)\end{array}$ & $\underset{(\mathrm{mg} . \%)}{\text { Serum Citrate }}$ \\
\hline $11 \cdot 4$ & $2 \cdot 5$ \\
\hline $10 \cdot 3$ & $3 \cdot 1$ \\
\hline $\begin{array}{l}12 \cdot 0 \\
11 \cdot 6\end{array}$ & $\begin{array}{l}1 \cdot 8 \\
2 \cdot 4\end{array}$ \\
\hline $\begin{array}{l}13 \cdot 5 \\
10.8 \\
11.0 \\
10.6\end{array}$ & $\begin{array}{l}0.7 \\
1.8 \\
3 \cdot 3 \\
3.7\end{array}$ \\
\hline $\begin{array}{l}14 \cdot 8 \\
14 \cdot 0 \\
12 \cdot 9 \\
10 \cdot 1 \\
10 \cdot 7\end{array}$ & $\begin{array}{l}0 \cdot 25 \\
2 \cdot 8 \\
1 \cdot 3 \\
4 \cdot 7 \\
2.9\end{array}$ \\
\hline $\begin{array}{l}12.0 \\
11.9 \\
10.8 \\
10.6 \\
13.6 \\
11.0 \\
11.0\end{array}$ & $\begin{array}{l}1 \cdot 9 \\
2 \cdot 3 \\
2 \cdot 1 \\
3 \cdot 5 \\
2 \cdot 4 \\
3 \cdot 0 \\
3 \cdot 0\end{array}$ \\
\hline $\begin{array}{r}11.4 \\
9.6 \\
10 \cdot 3\end{array}$ & $\begin{array}{l}2 \cdot 6 \\
4 \cdot 4 \\
3 \cdot 4\end{array}$ \\
\hline $10 \cdot 6$ & $2 \cdot 7$ \\
\hline $12 \cdot 4$ & $2 \cdot 5$ \\
\hline $10 \cdot 4$ & $2 \cdot 4$ \\
\hline $\begin{array}{r}9 \cdot 6 \\
10 \cdot 0\end{array}$ & $\begin{array}{l}5 \cdot 4 \\
2 \cdot 5\end{array}$ \\
\hline Mean $11 \cdot 4$ & $2 \cdot 7$ \\
\hline
\end{tabular}

citrate were made at various stages of the disease on seven patients. These are charted in Fig. 2, indicating that urinary citrate was low in the acute stage of the disease, rose with recovery and later tended to fall. We have taken the lower limit of normal to be in the region of $50 \mathrm{mg} . / 24 \mathrm{hr}$.

\section{Discussion}

Much of our knowledge of citrate metabolism has been derived from animal experiments. It has been established that levels are low in rickets and that citrate will promote healing, that the administration of vitamin $\mathrm{D}$ to rats receiving normal or rachitogenic diets increases tissue citrate content including that of blood and that concurrent elevations of serum calcium and serum citrate levels occur under the influence of vitamin D (Armstrong and Singer, 1956). The level of calcium in the diet also appears to have some influence on the citrate content of bones, higher citrate concentrations being observed with high calcium diets as opposed to calcium-deficient diets (Steenbock and Bellin, 1953; Carlsson and Hollunger, 1954). 


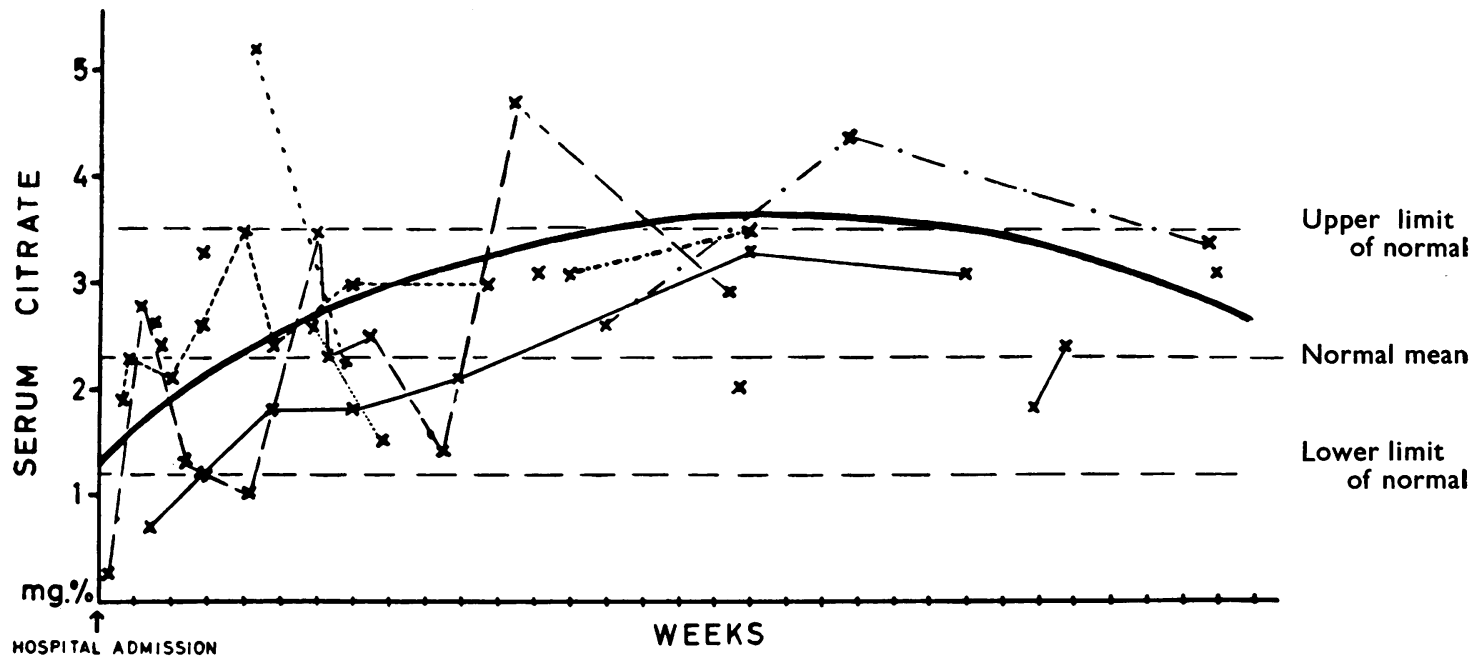

FIG. 1.-Serum citrate levels in 14 patients during the course of idiopathic hypercalcaemia.

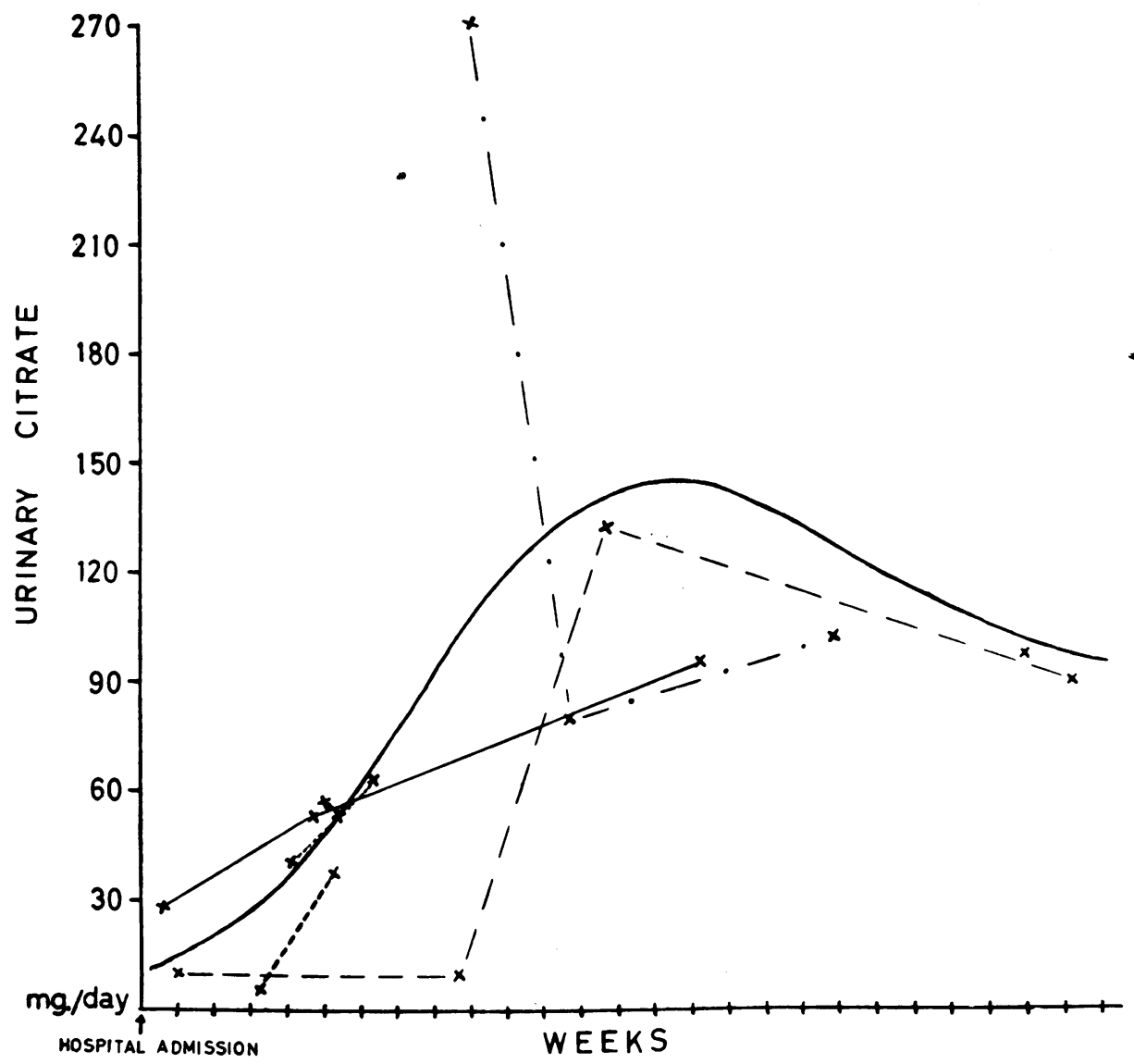

FIG. 2.-Urinary citrate levels in seven patients during the course of idiopathic hypercalcaemia. 
In the human, low blood citrate levels and a low urinary output of citrate have been observed in rachitic children. The levels rise with vitamin D administration (Harrison and Harrison, 1952). In hypervitaminosis $\mathrm{D}$ raised serum citrate levels up to $6 \mathrm{mg}$./100 ml. have been observed (Harrison, 1954).

Our findings of lowered serum citrate levels in blood and urine in the acute phase of idiopathic hypercalcaemia with a rise on withdrawal of vitamin $\mathrm{D}$ and recovery from the illness, and our evidence that the serum calcium level and serum citrate level are inversely related are thus apparently the reverse of those which would be expected with increased vitamin $\mathrm{D}$ activity. They appear to argue against increased vitamin $\mathbf{D}$ activity (when there is so much other evidence that it is present) or to suggest that the vitamin D-like action operates differently in respect of citrate metabolism. One should be very cautious, however, about applying to the period of infancy findings relevant to an older age group. Idiopathic hypercalcaemia is a peculiarly agelimited disease. At the age period at which it occurs hypervitaminosis $\mathbf{D}$ has indeed been reported to produce lowered serum citrate levels and a lowered urinary citrate output. Winberg and Zetterström (1956) observed these changes in an infant aged 11 months who over a period of five months had received $8,000,000$ units of vitamin $D$ and whose serum calcium level had risen to $16 \mathrm{mg} . / 100 \mathrm{ml}$. It may te that citrate metabolism in infancy and disorders of it conditioned by vitamin $\mathrm{D}$ and vitamin D-like substances show a different pattern from that seen at an older age.

\section{Summary}

Observations have been made on the normal serum citrate level in infancy $(1 \cdot 2-3 \cdot 5 \mathrm{mg} . / 100 \mathrm{ml}$.) and on the serum citrate level and urinary citrate output in idiopathic hypercalcaemia of infancy.

It is concluded that in idiopathic hypercalcaemia the serum citrate is low in the acute phase of the disease and rises up to or beyond the upper limit on recovery with a subsequent fall to average levels.

There is a statistically significant negative correlation between the serum calcium level and the serum citrate level in idiopathic hypercalcaemia.

The urinary output of citrate is low in the acute phase of the disease rising to normal levels with recovery.

We are greatly indebted to Dr. D. N. Nicholson and Dr. D. M. Douglas for allowing us access to patients under their charge and for generously making case records available to us.

\section{REFERENCES}

Armstrong, W. D. and Singer, L. (1956). In Ciba Foundation Symposium on Bone Structure and Metabolism, pp. 103-113. Churchill, London.

Bonham Carter, R. E., Dent, C. E., Fowler, D. I. and Harper, C. M. (1955). Arch. Dis. Childh., 30, 399.

Carlsson, A. and Hollunger, G. (1954). Acta physiol scand, 31, 317. Quoted by Nicolaysen, R. and Eeg-Larsen, N. In Ciba Foundation Symposium on Bone Structure and Metabolism, p. 181.

Churchill, London.
Creery, R. D. G. and Neill, D. W. (1954). Lancet, 2, 110

Daeschner, G. L. and Daeschner, C. W. (1957). Pediatrics, 19, 362.

Dawson, I. M. P., Craig, W. S. and Perera, F. J. C. (1954). Arch. Dis. Childh., 29, 475.

Dickens, F. (1941). Biochem. J., 35, 1011.

Dixon, T. F. (1956). In Ciba Foundation Symposium on Bone Structure and Metabolism, p. 113. Churchill, London.

Fanconi, G. (1956). In Ciba Foundation Symposium on Bone Structure and Metabolism, p. 189 . Churchill, London.

and de Chastonay, E. (1950). Helv. paedia. Acta, 5 Suppl. to no. 4 p. 5 .

Fellers, F. X. and Schwartz, R. (1958). A.M.A.J. Dis. Child., 96, 476.

Follis, R. H., Park, E. A. and Jackson, D. (1953). Bull. Johns Hopk. Hosp., 92, 426 .

Forfar, J. O. (1958). M.D. Thesis. University of St. Andrews. , Balf, C. L., Maxwell, G. M. and Tompsett, S. L. (1956). Lancet, 1, 981 .

Glover, M., Glover, J. and Morton, R. A. (1952). Biochem. J., 51, 1.

György, P. (1926). Jb. Kinderheilk., 112, 283. Quoted by Behrendt, H. (1949). Diagnostic Tests for Infants and Children. Interscience, New York.

Harrison, H. E. (1954). Pediatrics, 14, 285.

- and Harrison, H. C. (1952). Yale J. Biol. Med., 24, 273.

Hodges, R. G., Sperry, W. M. and Andersen, D. H.'(1943). Amer. J. Dis. Child., 65, 858 .

Jaffe, H. L. and Bodansky, A. (1943). J. Mt Sinai Hosp., 9, 901. Quoted by Behrendt, H. (1949). Diagnostic Tests for Infants and Children. Interscience, New York

Jelke, H. (1946). Acta med. scand., Suppl. 170, p. 345.

Kramer, B. and Tisdall, F. F. (1921). J. biol. Chem., 47, 475.

Lightwood, R. (1952). Arch. Dis. Childh., 27, 302.

Lowe, K. G., Henderson, J. L., Park, W. W. and McGreal, D. A. (1954). Lancet, 2, 101.

Macdonald, W. B. and Stapleton, T. (1955). Acta paediat. (Uppsala), 44,559 .

Morgan, H. G., Mitchell, R. G., Stowers, J. M. and Thomson, J. (1956). Lancet, 1, 925.

Raoul, Y., Le Boulch, N., Baron, C., Bazier, R. and Guerilot-Vinet, A. (1956). Bull. Soc. Chim. biol. (Paris), 38, 495. Quoted by Cook, R. P. (1958). Cholesterol Academic Press, New York.

Rafstedt, S. (1955). Studies on Serum Lipids and Lipoproteins in Infancy and Childhood. Lund.

Snell, F. D. and Snell, C. T. (1953). Colorimetric Methods of Analysis, 3rd ed., Vol. 3, p. 394. Van Nostrand, New York.

Stapleton, T. and Evans, I. W. J. (1955). Helv. paediat. Acta, 10, 149.

Steenbock, H. and Bellin, S. A. (1953). J. biol. Chem., 205, 985.

Taylor, T. G. (1953). Biochem. J., 54, 48.

Tisdall, F. F. (1923). J. biol. Chem., 56, 439

Trinder, P. Association of Clinical Biochemists, News Letter (No. 15), p. 17, Aug. 1957.

Winberg, J. and Zetterström, R. (1956). Acta paediat. (Uppsala), 45, 96.

Zak, B., Dickenman, R. C., White, E. G., Burnett, H. and Chemey, P. J.' (1955). Personal communication.

Zlatkis, A., Zak, B. and Boyle, A. J. (1953). J. Lab. clin. Med., 41, 486. 